\title{
A Selection Model for Soil Retaining Walls in Construction Projects
}

\author{
Jongsik Lee
}

Research Professor, Department of Architectural Engineering, Dankook University, South Korea

\begin{abstract}
Recently, there has been an increase in the size, diversification, and specialization of the construction methods of underground sites, particularly due to the need for more efficient utilization of underground spaces in downtown sites where space is limited and land prices high. This study presents a number of procedures that can be used to review site constraints and constructability, and to evaluate the economic efficiency and safety of soil retaining walls in order to select the optimum wall for the given site conditions. Furthermore, this study presents a quantitative analysis model to determine whether the selected soil retaining wall is able to deal with the site risks by using the forced decision method and binary weighting analysis. The study also presents a process model in order to select the optimum soil retaining wall for the given site conditions through the analysis of constructability, economic efficiency, stability and risk factors.
\end{abstract}

Keywords: construction management; construction method; construction planning; decision making

\section{Introduction}

\subsection{Background and purpose}

Due to limited space and high downtown land prices, the size of underground constructions has increased in order to make use of underground space for parking or commercial facilities, while the related construction methods have become more diversified and specialized. In particular, underground construction, which has a high impact on the whole project because it accounts for $20 \%$ to $40 \%$ of the total construction cost, is an important element of a successful project (e.g., Jung, K. J et al. 2003), and it requires careful planning and selection of the optimum method. However, there are no quantitative criteria concerning the selection of the soil retaining construction method, and it is mostly selected by the intuition of related engineers after simple data comparisons and review. As a result, the optimum soil retaining wall for a site cannot be selected, causing such problems as design changes, increased construction costs, delays, and soil collapse. Therefore, this study presents a quantitative soil retaining wall selection model that enables objective decision making and the systematic reflection of the experience and knowledge of staff.

\footnotetext{
*Contact Author: Jongsik Lee, Department of Architectural Engineering, Dankook University, Gyeonggi-do, 448-701, South Korea

Tel: +82-31-8005-4048 Fax: +82-31-8005-3741

E-mail: jslee725@gmail.com

(Received October 2, 2011 ; accepted August 30, 2012 )
}

\subsection{Scope and methods}

The scope of this study concerns the selection process for soil retaining walls in underground construction planning. The related literature as well as the existing underground construction method selection processes were reviewed, while the forced decision method ( $\mathrm{J}$. Fasal 1965) and binary weighting analysis (Oh, S. J 2004) to be applied in this study were examined. A selection process model was presented for the optimum soil retaining wall for the given site conditions based on safety, constructability, economic efficiency, and risks during construction planning. The process and main contents of this study are listed in Fig.1.

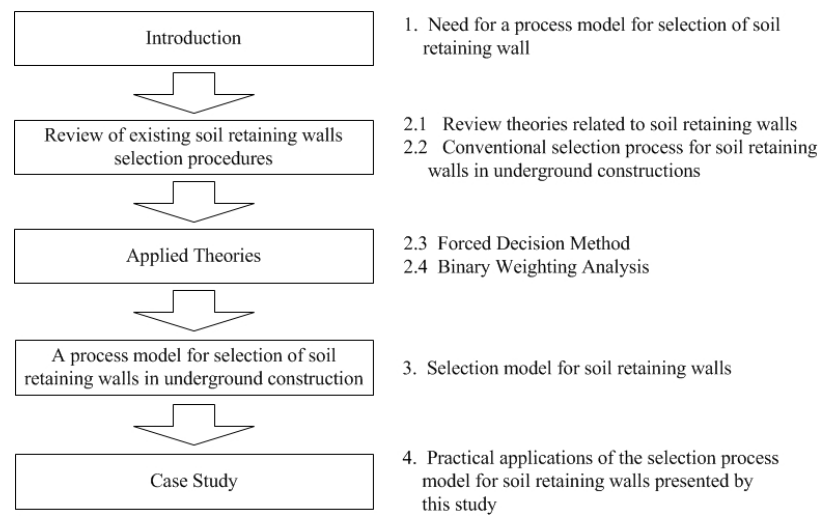

Fig.1. Study Procedure and Methodology

\section{Theoretical Review}

\subsection{Soil retaining wall}

The purposes of a soil retaining wall include safety, prevention of heaving (swelling of the excavated ground because the soil outside the retaining wall flows inside during soil retaining or excavation work), 
prevention of boiling (soaring of back sand to the excavated ground during the excavation of sandy ground), countermeasures regarding groundwater, and prevention of other damage.

\subsection{Conventional selection process for soil retaining walls}

While the conventional selection process for a soil retaining wall varies according to the site conditions, based on the author's past experiences, this was determined in most cases by the subjective judgment of the site staff. In the case of small projects, the soil retaining wall was selected by a simple comparison of different walls as shown in Table 1.

Table 1. Conventional Analysis for Selection of Soil Retaining Walls

\begin{tabular}{|c|c|c|c|c|c|}
\hline \multirow[b]{2}{*}{ Conditions } & \multirow[b]{2}{*}{ Factors } & \multicolumn{4}{|c|}{ Soil Retaining Walls } \\
\hline & & $\begin{array}{c}\text { H-pile } \\
+ \text { soil } \\
\text { wall }\end{array}$ & $\begin{array}{c}\text { Soil } \\
\text { Cement } \\
\text { Wall } \\
(\mathrm{SCW}) \\
\end{array}$ & $\begin{array}{c}\text { Cast In } \\
\text { concrete } \\
\text { Pile }(\mathrm{CIP})\end{array}$ & $\begin{array}{l}\text { Dia- } \\
\text { phragm } \\
\text { Wall }\end{array}$ \\
\hline \multirow{3}{*}{$\begin{array}{l}\text { Ground } \\
\text { Condition }\end{array}$} & $\begin{array}{c}\begin{array}{c}\text { Soft rock } \\
\text { story }\end{array} \\
\end{array}$ & B & A & A & A \\
\hline & $\begin{array}{c}\text { Hard rock } \\
\text { story }\end{array}$ & B & B & B & $\mathrm{B}$ \\
\hline & $\begin{array}{c}\text { Ground } \\
\text { water story }\end{array}$ & B & $\mathrm{B}$ & B & $\mathrm{B}$ \\
\hline \multirow{2}{*}{ Size } & Deep & $\mathrm{B}$ & $\mathrm{A}$ & $\mathrm{A}$ & A \\
\hline & Wide & $\mathrm{B}$ & $\mathrm{A}$ & A & $\mathrm{A}$ \\
\hline Rigidity & $\begin{array}{c}\text { Wall } \\
\text { bending } \\
\text { rigidity }\end{array}$ & B & A & A & A \\
\hline \multirow{3}{*}{ Pollution } & $\begin{array}{c}\text { Noise, } \\
\text { Vibration }\end{array}$ & B & B & B & B \\
\hline & $\begin{array}{c}\text { Surround- } \\
\text { ing land } \\
\text { settlement }\end{array}$ & B & A & A & A \\
\hline & $\begin{array}{l}\text { Backwater } \\
\text { Treatment }\end{array}$ & B & $\mathrm{C}$ & $\mathrm{C}$ & A \\
\hline $\begin{array}{c}\text { Construc- } \\
\text { tion Period }\end{array}$ & $\begin{array}{c}\text { Construc- } \\
\text { tion Period }\end{array}$ & A & $\mathrm{C}$ & $\mathrm{C}$ & $\mathrm{C}$ \\
\hline \multicolumn{2}{|c|}{ Cost } & A & $\mathrm{C}$ & $\mathrm{C}$ & $\mathrm{C}$ \\
\hline \multicolumn{2}{|c|}{ Stagnant Water } & $\mathrm{B}$ & $\mathrm{B}$ & $\mathrm{B}$ & A \\
\hline
\end{tabular}

Note: A - Possible, B - Average, C - Difficult

\subsection{Forced decision method}

While preparations for various risks concerning underground construction must be made, it is difficult to plan perfect countermeasures for every expected risk. Therefore, the major risks that must be considered according to site conditions were identified and the forced decision method was used to determine the priority of each risk. The forced decision method involves evaluating the importance of a risk through pair-wise comparison between risks in order to determine the priority of each risk (Lee, D. H 2006). Specifically, the relative priority of each function is given a score of either ' 1 ' or ' 0 ' in comparison to another risk, and the scores are summed up for each function. The forced decision method enables a decision to be made about which risks in a specific site must be given higher priority when selecting a soil retaining wall.

\subsection{Binary weighting analysis}

This selection method evaluates each soil retaining wall to determine whether it is able to deal with each risk. If the soil retaining wall is appropriate for a given risk, Yes is assigned to the method concerning the risk; otherwise, No is assigned as shown in Table 2. The value 1 is then given for Yes and 0 for No. The final value is then converted to a binary number, which is converted to a decimal number again to determine the evaluation result as in Eq. (1), (2) and (3). The more satisfactory the review factors are, the larger the Equivalent Decimal Value is and according to the formula (3), the Rating Value is between 0 and 1. If the method satisfies every factor, the Rating Value becomes 1 . If not, it becomes 0 . In other words, the larger the Rating Value is, the more suitable the method is.

Table 2. Binary Weighting Analysis (Example)

\begin{tabular}{c|c|c}
\hline Factor & Yes & No \\
\hline \hline $\mathrm{A}$ & $\bullet$ & $\bullet$ \\
\hline $\mathrm{B}$ & & \\
\hline $\mathrm{C}$ & $\bullet$ & $\bullet$ \\
\hline $\mathrm{D}$ & & $\bullet$ \\
\hline $\mathrm{E}$ & & \\
\hline
\end{tabular}

$$
\begin{aligned}
E D V & =\sum_{i=1}^{n}\left(w_{i} \cdot 2^{i-1}\right) \\
& =1 \cdot 2^{5-1}+0 \cdot 2^{4-1}+1 \cdot 2^{3-1}+0 \cdot 2^{2-1}+0 \cdot 2^{1-1}=20
\end{aligned}
$$

$$
\begin{aligned}
\operatorname{MEDV} & =\sum_{i=1}^{n}\left(1 \cdot 2^{i-1}\right) \\
& =1 \cdot 2^{5-1}+1 \cdot 2^{4-1}+1 \cdot 2^{3-1}+1 \cdot 2^{2-1}+1 \cdot 2^{1-1}=31
\end{aligned}
$$

$R V=E D V / M E D V=20 / 31=0.645$

Where

$\boldsymbol{R} \boldsymbol{V}$ : Rating Value

MEDV : Maximum Equivalent Decimal Value

$\boldsymbol{E D V}$ : Equivalent Decimal Value

$\boldsymbol{w}_{\boldsymbol{i}}$ : The value en-downed to the $\boldsymbol{i}$ factor, Value 1 given for 'Yes' and 0 for ' $N$ ' $^{\prime}$

$\boldsymbol{i}$ : The arranged location of the factor

\section{Process Model for Selection of Soil Retaining Walls}

Using the process model for the selection of soil retaining walls used in this study, the optimum soil retaining wall for a site was selected through a review of the constraints of the site and ground, a review of the economic efficiency and safety of the soil retaining wall, and a review of the risks. Fig.2. shows a summary of the review details in each step of the selection process for the optimum soil retaining wall for a site, which is proposed by this study and the applied theory. (1) Constraints review

In the constraints review, which is the first step in the soil retaining wall selection process, the 


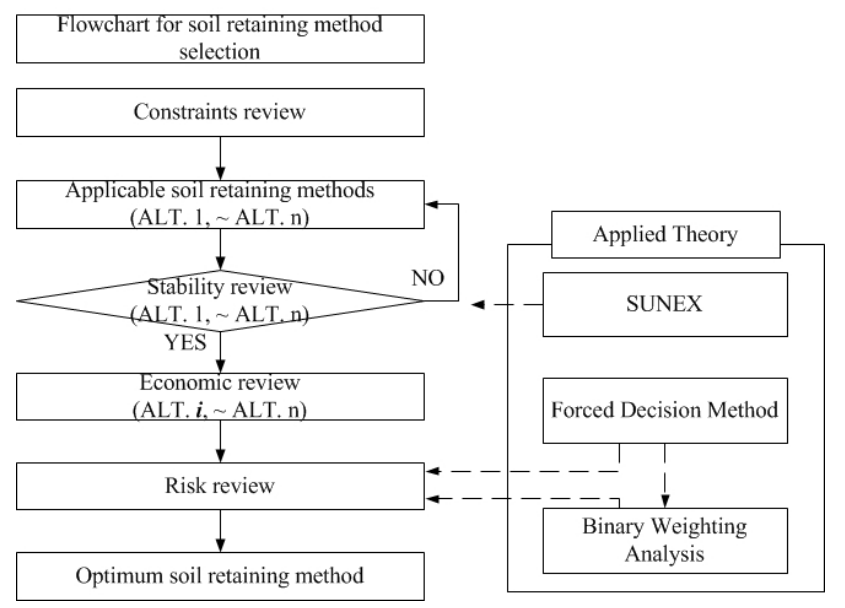

Fig.2. Selection Model for Soil Retaining Walls

Table 3. Review Factors for Project Constraints (Partial)

\begin{tabular}{l|l}
\hline & Factor \\
\hline \hline 1 & Client requirements \\
\hline 3 & Local districts \\
\hline 4 & Construction period \\
\hline 5 & Suilding structure \\
\hline 6 & Uurrounding environment \\
\hline 7 & Foundation excavation depth \\
\hline 8 & Foundation excavation area \\
\hline 9 & Construction size \\
\hline 10 & Building area \\
\hline 11 & Land area \\
\hline 13 & Groundwater contamination problems \\
\hline 14 & Neighboring structures \\
\hline 15 & Notable surrounding structures \\
\hline 16 & Difference of elevation \\
\hline 17 & Surrounding roads \\
\hline 18 & Underground utilities \\
\hline 19 & Important neighboring facilities \\
\hline 20 & Surrounding environmental pollution problems \\
\hline 21 & Existence of underground structures \\
\hline 22 & Distance to neighboring buildings \\
\hline & Surrounding road surface condition \\
\hline &
\end{tabular}

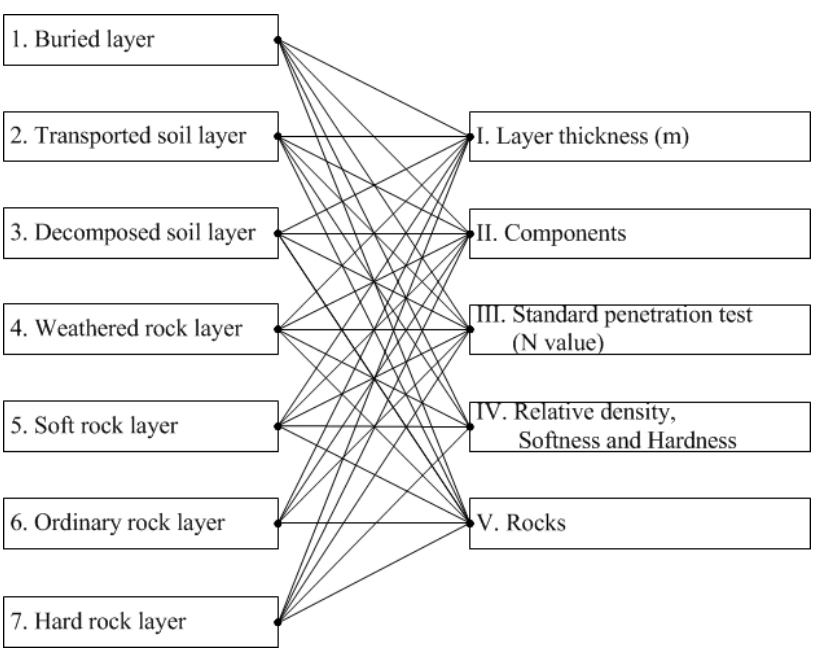

Fig.3. Constraints Review for Ground Conditions (Example)
Table 4. Constructability Review Factors

\begin{tabular}{l|l}
\hline Category & Review Factors \\
\hline \hline Topography & $\begin{array}{l}\text { Is there a difference of elevation in and around } \\
\text { the site? }\end{array}$ \\
\cline { 2 - 2 } & Does the rock condition need to be considered? \\
\cline { 2 - 2 } & $\begin{array}{l}\text { Does the transportation path for construction } \\
\text { equipment and materials need to be considered? }\end{array}$ \\
\cline { 2 - 3 } & $\begin{array}{l}\text { Does sequential load according to traffic need } \\
\text { to be considered? }\end{array}$ \\
\hline & $\begin{array}{l}\text { Does the general topography around the site } \\
\text { need to be considered? }\end{array}$
\end{tabular}

Influence on Does the foundation penetration depth need to neighboring be considered?

\begin{tabular}{l|l} 
structures & Are there neighboring structures that need to be
\end{tabular} considered?

Does the foundation type need to be considered?

Does the influence of noise and vibration to neighboring structures need to be considered?

Does the distance between temporary structures and existing structures need to be considered?

Do the properties of the ground in the area affect the safety of temporary facilities and need to be considered?

Does the degree of consolidated settlement of the ground around the site need to be considered?

\begin{tabular}{l|l}
\hline Location & Is the site in a downtown area? \\
\cline { 2 - 2 } conditions & Does the site boundary need to be checked? \\
\cline { 2 - 2 } & $\begin{array}{l}\text { Do the neighboring structures interfere with } \\
\text { clearance? }\end{array}$ \\
\cline { 2 - 2 } & Are the stuctures that requre caution?
\end{tabular}

Are there structures that require caution? (e.g., subways)

Is there a concern about damage due to noise during construction?

Is there a concern about damage due to vibration during construction?

Underground Do they affect the foundations of existing utilities and structures?

\begin{tabular}{l|l} 
obstacles & Were there wells in the past?
\end{tabular}

Were there riverbanks in the past?

Do the location, size, structure, and deterioration of gas pipes need to be investigated?

Do the location, size, structure, and deterioration of water supply pipes need to be investigated?

Do the location, size, structure, and deterioration of sewer pipes need to be investigated?

Do the location, size, structure, and deterioration of electric cable pipes need to be investigated?

\begin{tabular}{l|l}
\hline Seasonal & Are preparations for rainfall and local
\end{tabular} weather downpour necessary?

Does the existence of wells need to be checked?

\begin{tabular}{l|l}
\hline Road and & Does the road type need to be considered?
\end{tabular}

\begin{tabular}{l|l} 
traffic & Does the road structure need to be considered?
\end{tabular}

$\begin{array}{ll}\text { conditions } & \text { Does the restriction of traffic need to be }\end{array}$ considered?

\begin{tabular}{l|l}
\hline Others & Is a review of related laws or preparation for
\end{tabular} restrictions necessary? 
project constraints were included, such as the client requirements, construction size, neighboring structures, elevation differences, surrounding road surface conditions, and ground conditions, including soil quality. Table 3 . and Fig.3. provide lists of the constraints review items.

\section{(2) Constructability review}

In this step, the ease of construction of the soil retaining wall is evaluated as well as the factors that may affect the constructability on the site, including the location of the site, elevation differences, rock conditions, ease of operation of the construction equipment, conditions of structures close to the site and surrounding ground, buried utilities, expected weather during the construction period, and road and traffic conditions. Table 4 . lists the items for a constructability review for an underground wall retaining construction.

(3) First selection of soil retaining walls

Based on the results of constraints and constructability reviews, the first selection of soil retaining walls that can be applied to the given site is made using Tables 5. and 6., which were reorganized from the related research and practical data.

Table 5. Applicable Quality of Soil for Retaining Wall

\begin{tabular}{l|l}
\hline \multicolumn{1}{c|}{ Method } & \multicolumn{1}{c}{ Applied Soil } \\
\hline \hline H-pile + Soil wall & All geological strata \\
\hline CIP & $\begin{array}{l}\text { All grounds excluding boulder and rock } \\
\text { layers }\end{array}$ \\
\hline SCW & $\begin{array}{l}\text { Ground with clay and sand of N-value } \\
<50\end{array}$ \\
\hline Diaphragm wall & All geological strata \\
\hline
\end{tabular}

\section{(4) Stability review}

For a stability review of a soil retaining wall, this study used the SUNEX (elasto-plastic analysis of Step Underground Excavation) method, a soil retaining wall structure calculation program with expanded functions and improved usability while considering both the Yamagata expansion method and the Morishige method among the elasto-plastic beam methods (Seo, J. H 2000).

(5) Economic review

The economic review of each soil retaining wall calculates the schematic construction cost of the walls, and uses the comparison of costs for selection of the final wall.

(6) Risks review and selection of soil retaining wall

The possible risks that may occur during an underground construction are classified as design conditions, structural conditions, ground conditions, site conditions, economic conditions, and environmental conditions. The forced decision method is then used for a comparative analysis of the risks. On the basis of the comparative analysis results, the priorities of risks that must be managed during construction are determined, and the binary weighting analysis is carried out with the priorities of the selected soil retaining walls.

(1) Risk review;

While it is difficult to predict which site conditions will act as risks during construction, the review and preparation for risks is a critical task. This review of risks is an important activity used to select the optimum construction methods that can be applied to each step of the selection process. Thus, through an analysis of related literature and case studies, in this study the risks that may occur in the soil retaining wall construction site for a building are classified into: design conditions, ground conditions, site conditions, environmental conditions, construction conditions, structural conditions, and economic conditions. The risk review items proposed in this study are summarized in Table 7.

(2) Application of the forced decision method to derive risks;

The forced decision method used to determine which risks must be considered before other construction conditions, is managed in a focused manner. The priorities of risks provide the criteria for determining the optimum soil retaining wall for the site by weighting each risk, and the priories determined by the forced decision method are unique for each site and can be used as case data (N. Yau and J. Yang 1998) for the selection of a soil retaining wall for similar sites in the future. Table 8 . shows an example of the determination of risk priorities using the forced decision method in which the risks, ranging from design conditions to economic conditions, are compared with each other,

Table 6. Selection Criteria for Soil Retaining Walls According to Ground Conditions

\begin{tabular}{|c|c|c|c|c|c|c|c|c|c|c|c|}
\hline & & & \multirow{3}{*}{$\begin{array}{l}\text { Depth } \\
\text { (m) }\end{array}$} & \multirow{3}{*}{$\begin{array}{l}\text { Water } \\
\text { shielding } \\
\text { performance }\end{array}$} & \multirow{3}{*}{$\begin{array}{l}\text { Vibration } \\
\& \text { Noise }\end{array}$} & \multicolumn{6}{|c|}{ Soil Quality } \\
\hline & & & & & & \multirow{2}{*}{ Rocks } & \multirow{2}{*}{ Boulder } & \multirow{2}{*}{ Gravel } & \multirow{2}{*}{ Sand } & \multicolumn{2}{|c|}{ Clay } \\
\hline & & & & & & & & & & Soft & Hard \\
\hline \multirow{3}{*}{$\begin{array}{l}\text { H-pile + } \\
\text { Soil Wall }\end{array}$} & \multicolumn{2}{|c|}{ Conventional type } & 20 & $\mathrm{C}$ & $\mathrm{C}$ & $\mathrm{C}$ & $\mathrm{B}$ & $\mathrm{A}$ & $\mathrm{A}$ & $\mathrm{A}$ & $\mathrm{A}$ \\
\hline & \multicolumn{2}{|c|}{ Auger-combined press-in } & 25 & $\mathrm{C}$ & $\mathrm{A}$ & $\mathrm{C}$ & $\mathrm{C}$ & $\mathrm{A}$ & $\mathrm{A}$ & $\mathrm{A}$ & $\mathrm{A}$ \\
\hline & \multicolumn{2}{|c|}{ Field mortar piles } & 36 & $\mathrm{C}$ & $\mathrm{A}$ & $\mathrm{A}$ & $\mathrm{B}$ & $\mathrm{A}$ & $\mathrm{A}$ & $\mathrm{A}$ & $\mathrm{A}$ \\
\hline \multirow{2}{*}{ CIP } & \multicolumn{2}{|c|}{ Conventional type } & 36 & $\mathrm{~B}$ & $\mathrm{~A}$ & $\mathrm{~A}$ & $\mathrm{~A}$ & $\mathrm{~A}$ & $\mathrm{~A}$ & A & A \\
\hline & \multicolumn{2}{|c|}{ Impermeable type } & 30 & $\mathrm{~B}$ & $\mathrm{~A}$ & $\mathrm{~A}$ & $\mathrm{~B}$ & $\mathrm{~A}$ & $\mathrm{~A}$ & $\mathrm{~A}$ & $\mathrm{~A}$ \\
\hline \multirow{2}{*}{$\mathrm{SCW}$} & \multicolumn{2}{|c|}{ Shape steel } & 30 & $\mathrm{~A}$ & $\mathrm{~A}$ & $\mathrm{C}$ & $\mathrm{B}$ & $\mathrm{A}$ & $\mathrm{A}$ & $\mathrm{A}$ & $\mathrm{A}$ \\
\hline & \multicolumn{2}{|l|}{ Steel pipe } & 30 & $\mathrm{~A}$ & $\mathrm{~A}$ & $\mathrm{C}$ & $\mathrm{C}$ & $\mathrm{A}$ & $\mathrm{A}$ & A & $\mathrm{A}$ \\
\hline \multirow{2}{*}{$\begin{array}{l}\text { Diaphragm } \\
\text { Wall }\end{array}$} & \multirow{2}{*}{$\begin{array}{l}\text { Field concrete } \\
\text { wall }\end{array}$} & Drill & 100 & $\mathrm{~A}$ & $\mathrm{~A}$ & $\mathrm{~A}$ & $\mathrm{C}$ & A & A & $\mathrm{A}$ & A \\
\hline & & Bucket & 50 & A & A & $\mathrm{C}$ & $\mathrm{A}$ & $\mathrm{A}$ & $\mathrm{A}$ & $\mathrm{A}$ & $\mathrm{A}$ \\
\hline
\end{tabular}

Note: A - Possible, B - Average, C- Difficult 
Table 7. Risk Review Factors

\begin{tabular}{|c|c|}
\hline Review Factor & Details \\
\hline Design conditions & $\begin{array}{l}\text { Applied load, soil parameters, reliability } \\
\text { of soil retaining model, reliability of } \\
\text { subsidiary methods. }\end{array}$ \\
\hline Ground conditions & $\begin{array}{l}\text { Ground property (e.g., soft layer, } \\
\text { conglomerate layer), groundwater } \\
\text { condition, support layer condition, } \\
\text { support layer depth. }\end{array}$ \\
\hline Site conditions & $\begin{array}{l}\text { Difference of elevation in the site, } \\
\text { planar shape (standard/nonstandard), } \\
\text { site size, relationship with neighboring } \\
\text { land. }\end{array}$ \\
\hline $\begin{array}{l}\text { Environmental } \\
\text { conditions }\end{array}$ & $\begin{array}{l}\text { Noise, vibration, settlement of } \\
\text { surrounding land, treatment of } \\
\text { discharged muddy water, contamination } \\
\text { of groundwater. }\end{array}$ \\
\hline $\begin{array}{l}\text { Construction } \\
\text { conditions }\end{array}$ & $\begin{array}{l}\text { Ground collapse, change of applied } \\
\text { load, earthquake, neighboring } \\
\text { constructions, water leakage, failure of } \\
\text { excavation base. }\end{array}$ \\
\hline Structural conditions & $\begin{array}{l}\text { Bending rigidity of soil retaining wall, } \\
\text { stagnant water, properties of structures. }\end{array}$ \\
\hline Economic conditions & $\begin{array}{l}\text { Construction period, construction cost, } \\
\text { material management, productivity. }\end{array}$ \\
\hline
\end{tabular}

Table 8. Priority of Risk Review Factors using the Forced Decision Method (Example)

\begin{tabular}{|c|c|c|c|c|c|c|c|c|c|}
\hline Review Factor & 1 & 2 & 3 & 4 & 5 & 6 & 7 & Total & Priority \\
\hline $\begin{array}{l}\text { Design } \\
\text { conditions }\end{array}$ & & 0 & 1 & 1 & 1 & 0 & 1 & 4 & 2 \\
\hline $\begin{array}{l}\text { Ground } \\
\text { conditions }\end{array}$ & 1 & & 1 & 1 & 1 & 1 & 1 & 6 & 1 \\
\hline Site conditions & 0 & 0 & & 1 & 0 & 0 & 0 & 1 & 5 \\
\hline $\begin{array}{l}\text { Environmental } \\
\text { conditions }\end{array}$ & 0 & 0 & 0 & & 1 & 1 & 1 & 3 & 3 \\
\hline $\begin{array}{l}\text { Construction } \\
\text { conditions }\end{array}$ & 0 & 0 & 1 & 0 & & 1 & 0 & 2 & 4 \\
\hline $\begin{array}{l}\text { Structural } \\
\text { conditions }\end{array}$ & 1 & 0 & 1 & 0 & 0 & & 0 & 2 & 4 \\
\hline $\begin{array}{l}\text { Economic } \\
\text { conditions }\end{array}$ & 0 & 0 & 1 & 0 & 1 & 1 & & 3 & 3 \\
\hline
\end{tabular}

and either ' 0 ' or ' 1 ' is assigned to each to indicate importance. If the design conditions are more important than the ground conditions for a risk, 1 is assigned to the design conditions and 0 is assigned to the ground conditions. In this way, each item is compared with another item. The values in each row are then summed up, and the priority is determined for each risk.

(3) Selection of soil retaining wall using binary weighting analysis;

The priorities of risks determined by the forced decision method are factors for the selection of the optimum soil retaining wall for a site. As shown in Table 9., each wall is weighted and quantified by binary weighting analysis to determine the risk correspondence, which determines the degree of correspondence for each wall to the risk. This result is then combined with the stability review and economic
Table 9. Evaluation using Binary Weighting Analysis

\begin{tabular}{l|l|l|l}
\hline & Risk Review Items & Yes & No \\
\hline \hline $\begin{array}{l}\text { Ground } \\
\text { conditions }\end{array}$ & $\begin{array}{l}\text { Is the wall restricted by ground } \\
\text { conditions, including soil quality, } \\
\text { groundwater level, and coefficient of } \\
\text { hydraulic conductivity? }\end{array}$ & & \\
\hline $\begin{array}{l}\text { Design } \\
\text { conditions }\end{array}$ & $\begin{array}{l}\text { Are the water discharge and water } \\
\text { shielding plans appropriate? }\end{array}$ & & \\
\hline $\begin{array}{l}\text { Environmental } \\
\text { conditions }\end{array}$ & $\begin{array}{l}\text { Can the surrounding structures cope } \\
\text { with the influences (e.g., settlement } \\
\text { of surrounding ground, noise, } \\
\text { vibration)? }\end{array}$ & & \\
\hline $\begin{array}{l}\text { Economic } \\
\text { conditions }\end{array}$ & $\begin{array}{l}\text { Is the economic efficiency } \\
\text { (construction period, construction } \\
\text { cost) excellent? }\end{array}$ & & \\
\hline $\begin{array}{l}\text { Construction } \\
\text { conditions }\end{array}$ & $\begin{array}{l}\text { Can you cope with work area } \\
\text { limitation and failure of excavation } \\
\text { base? }\end{array}$ & & \\
\hline $\begin{array}{l}\text { Structural } \\
\text { conditions }\end{array}$ & $\begin{array}{l}\text { Are the structural conditions such as } \\
\text { rigidity, properties of structures, and } \\
\text { connections of structures excellent? }\end{array}$ & & \\
\hline Site conditions & $\begin{array}{l}\text { Is the wall appropriate for the } \\
\text { size, difference of elevation, and } \\
\text { configuration of the site? }\end{array}$ & & \\
\hline
\end{tabular}

review in the previous steps to select the optimum soil retaining wall for the site. The priorities determined by the forced decision method become the criteria for allocating weights in the binary weighting analysis.

(4) Correlations between forced decision method and binary weighting analysis;

For a combination of the forced decision method and binary weighting analysis in sites that have different constraints, the priorities determined by the forced decision method provide the basis for weights in the binary weighting analysis, as shown in Fig.4. Specifically, the risks that are determined by the forced decision method should be considered before others are positioned at a higher level on the list and are given higher weights in the binary weighting analysis.

\section{Case Study}

The case study for this research was a commercial building with 8 floors underground and 16 floors above ground. The building was to be newly constructed on a $6,950 \mathrm{~m}^{2}$ site located in downtown Seoul, which is Korea's capital. The constraint was to construct a subway passage that was close to the first and second underground floors of the building, and the client demanded that the construction be completed six months earlier than planned as shown in Table 10.

Table 10. Results of Constraints Review

\begin{tabular}{l|l}
\hline Factor & Review \\
\hline \hline Client requirements & $\begin{array}{l}\text { Shorten the construction } \\
\text { duration (36 months } \rightarrow 30 \\
\text { months) }\end{array}$ \\
\hline Local districts & $\begin{array}{l}\text { General commercial district, } \\
\text { aesthetic area }\end{array}$ \\
\hline Construction period & - \\
\hline Building structure & Steel frame, reinforced concrete \\
\hline Surrounding environment & Low-story housing, subway. \\
\hline
\end{tabular}




\begin{tabular}{l|l}
\hline Underground structure & Reinforced concrete \\
\hline Foundation excavation depth & $35 \mathrm{~m}$ \\
\hline Foundation excavation area & $6,139 \mathrm{~m}^{2}$ \\
\hline Building size & $\begin{array}{l}8 \text { floors underground, 16 floors } \\
\text { above ground }\end{array}$ \\
\hline Building area & $4,072.85 \mathrm{~m}^{2}$ \\
\hline Land area & $6,950.70 \mathrm{~m}^{2}$ \\
\hline $\begin{array}{l}\text { Groundwater contamination } \\
\text { problem }\end{array}$ & $\begin{array}{l}\text { Concern for contamination } \\
\text { of groundwater when ground } \\
\text { reinforcement method is used }\end{array}$ \\
\hline Neighboring structures & Low-story housing \\
\hline Notable surrounding structures & $\begin{array}{l}\text { Subway line } 3 \\
\text { (Located 25m to the west of the } \\
\text { site) }\end{array}$ \\
\hline Difference of elevation & Relatively flat \\
\hline $\begin{array}{l}\text { Surrounding roads } \\
\text { Trunk road } 25 \mathrm{~m} \text { in front to the } \\
\text { northwest }\end{array}$ \\
\hline $\begin{array}{l}\text { Underground utilities } \\
\text { Important neighboring } \\
\text { facilities }\end{array}$ & Sone \\
\hline $\begin{array}{l}\text { Surrounding environmental } \\
\text { pollution problems }\end{array}$ & Noise and vibration \\
\hline $\begin{array}{l}\text { Existence of underground } \\
\text { structures }\end{array}$ & None \\
\hline $\begin{array}{l}\text { Distance to neighboring } \\
\text { buildings }\end{array}$ & Close \\
\hline $\begin{array}{l}\text { Surrounding road surface } \\
\text { condition }\end{array}$ & Good \\
\hline
\end{tabular}

After understanding the soil quality and rock conditions of the case site as in Table 11.

Table 11. Results of Ground Conditions Review

\begin{tabular}{l|l|l|l|l|l}
\hline & $\begin{array}{l}\text { Layer } \\
\text { thickness } \\
(\mathrm{m})\end{array}$ & $\begin{array}{l}\text { Com- } \\
\text { ponents }\end{array}$ & $\begin{array}{l}\text { Stand- } \\
\text { ard pene- } \\
\text { tration test } \\
\text { (N value })\end{array}$ & $\begin{array}{l}\text { Relative } \\
\text { density and } \\
\text { oftness/ } \\
\text { hardness }\end{array}$ & Rocks \\
\hline \hline $\begin{array}{l}\text { Buried } \\
\text { layer }\end{array}$ & $1.4 \sim 4.1$ & $\begin{array}{l}\text { Sand with } \\
\text { gravel } \\
\text { and silt }\end{array}$ & $\begin{array}{l}2 / 30 \sim 50 \\
/ 10\end{array}$ & $\begin{array}{l}\text { Very loose } \\
\text { - Very } \\
\text { dense }\end{array}$ & - \\
\hline $\begin{array}{l}\text { Transported } \\
\text { soil layer }\end{array}$ & $3.3 \sim 8.9$ & $\begin{array}{l}\text { Gravel } \\
\text { with silt } \\
\text { and sand }\end{array}$ & $\begin{array}{l}2 / 30 \sim 50 \\
/ 16\end{array}$ & $\begin{array}{l}\text { Very weak } \\
\text { - Solid, } \\
\text { Loose- } \\
\text { Very dense }\end{array}$ & - \\
\hline $\begin{array}{l}\text { Decomposed } \\
\text { soil layer }\end{array}$ & $0.6 \sim 11.5$ & $\begin{array}{l}\text { Gravel } \\
\text { with silt }\end{array}$ & $\begin{array}{l}17 / 30 \sim 50 \\
/ 11\end{array}$ & $\begin{array}{l}\text { Average } \\
\text { dense - } \\
\text { Very dense }\end{array}$ & - \\
\hline $\begin{array}{l}\text { Weathered } \\
\text { rock layer }\end{array}$ & $0.8 \sim 9.9$ & - & $\begin{array}{l}50 / 10 \sim 50 \\
/ 3\end{array}$ & Very hard & \\
\hline $\begin{array}{l}\text { Soft rock } \\
\text { layer }\end{array}$ & $1.5 \sim 13.0$ & - & - & - & Gneiss \\
\hline $\begin{array}{l}\text { Ordinary } \\
\text { rock layer }\end{array}$ & $2.0 \sim 6.0$ & - & - & - & Gneiss \\
\hline $\begin{array}{l}\text { Hard rock } \\
\text { layer }\end{array}$ & $3.0 \sim 21.4$ & - & - & - & Gneiss \\
\hline
\end{tabular}

Review Results

Finally applied soil quantity; Understanding of rock conditions

Joints and cracks are developed / $q_{u} \geq 147.10 \mathrm{Mpa}$

Note: $q_{u}$-Unconfined compression strength

The authors chose H-pile + soil wall, CIP, SCW, and Diaphragm Wall as the primary soil retaining walls that could be applied. After stability and economic efficiency reviews were carried out on each wall, it was found that the selected walls had no stability problems when they were correctly designed. In terms of the economic efficiency review, the Diaphragm Wall was more expensive than other walls when only construction costs were considered. However, when it was considered that the structure can be permanent after construction and that the construction period can be shortened, the Diaphragm Wall demonstrated high economic efficiency, as shown in Table 12.

Table 12. Stability Review for Soil Retaining Walls

\begin{tabular}{l|l|l}
\hline & H-pile+ Soil Wall & CIP \\
\hline \hline $\begin{array}{l}\text { Body } \\
(\mathrm{mm})\end{array}$ & $\begin{array}{l}\text { H-pile: } \\
400 \times 300 \times 10 \times 16\end{array}$ & $\begin{array}{l}\text { CIP : Ø400, } \\
\text { H-pile: } \\
300 \times 300 \times 10 \times 5\end{array}$ \\
\hline $\begin{array}{l}\text { Brace } \\
(\mathrm{mm})\end{array}$ & H-pile: & $\begin{array}{l}\text { H-pile: } \\
300 \times 300 \times 10 \times 15\end{array}$ \\
\hline $\begin{array}{l}\text { Maximum } \\
\text { displacement }\end{array}$ & $101.3 \mathrm{~mm}$ & $52.6 \mathrm{~mm}$ \\
\hline \hline $\begin{array}{l}\text { Body } \\
(\mathrm{mm})\end{array}$ & SCW & Diaphragm Wall \\
\hline $\begin{array}{l}\text { Brace } \\
(\mathrm{mm})\end{array}$ & $400 \times 300 \times 13 \times 21$ & $\begin{array}{l}\text { Iron bar: SD 40, } \\
\mathrm{f}_{\mathrm{y}}=392.27 \mathrm{Mpa}, \\
\mathrm{f}_{\mathrm{ck}}=29.42 \mathrm{Mpa}\end{array}$ \\
\hline $\begin{array}{l}\text { Maximum } \\
\text { displacement }\end{array}$ & $\begin{array}{l}\text { H-pile: } \\
300\end{array}$ \\
\hline
\end{tabular}

Note: Ø- Diameter, SD-Steel bar Diameter, $\mathrm{f}_{\mathrm{ck}}$-Compression strength, $\mathrm{f}_{\mathrm{y}}$-Yield strength

In order to identify the risks in the site and the importance of the risks, the risks were analyzed using the forced decision method, with five specialists both inside and outside the company, as shown in Table 13. A risk analysis was conducted and it was found that the risks that must be considered to have a higher priority than others were weighted in the following order: environmental conditions, ground conditions, design conditions, construction conditions, structural conditions, and economic conditions. It was considered that this result was due to the increasing interest in the environment among people, and the consideration of disputes due to civil complaints.

Table 13. Result of Risk Priority

\begin{tabular}{l|c|c|c|c|c|c|c}
\hline & A & B & C & D & E & F & G \\
\hline \hline Specialist 1 & 0 & 2 & 1 & 3 & 4 & 5 & 6 \\
\hline Specialist 2 & 2 & 4 & 0 & 3 & 1 & 6 & 5 \\
\hline Specialist 3 & 1 & 5 & 2 & 6 & 3 & 4 & 0 \\
\hline Specialist 4 & 1 & 3 & 5 & 0 & 4 & 2 & 6 \\
\hline Specialist 5 & 1 & 0 & 2 & 4 & 3 & 5 & 6 \\
\hline
\end{tabular}

\begin{tabular}{l|c|c|c|c|c|c|c}
\hline $\begin{array}{l}\text { Group weight } \\
\text { (Average of } \\
\text { weights) }\end{array}$ & 1 & 2.8 & 2 & 3.2 & 3 & 4.4 & 4.6 \\
\hline Ranking & 7 & 5 & 6 & 3 & 4 & 2 & 1 \\
\hline
\end{tabular}

Note: A-Economic conditions, B-Structural conditions, C-Site conditions, D-Design conditions, E-Construction conditions, F-Ground conditions, G-Environmental conditions 


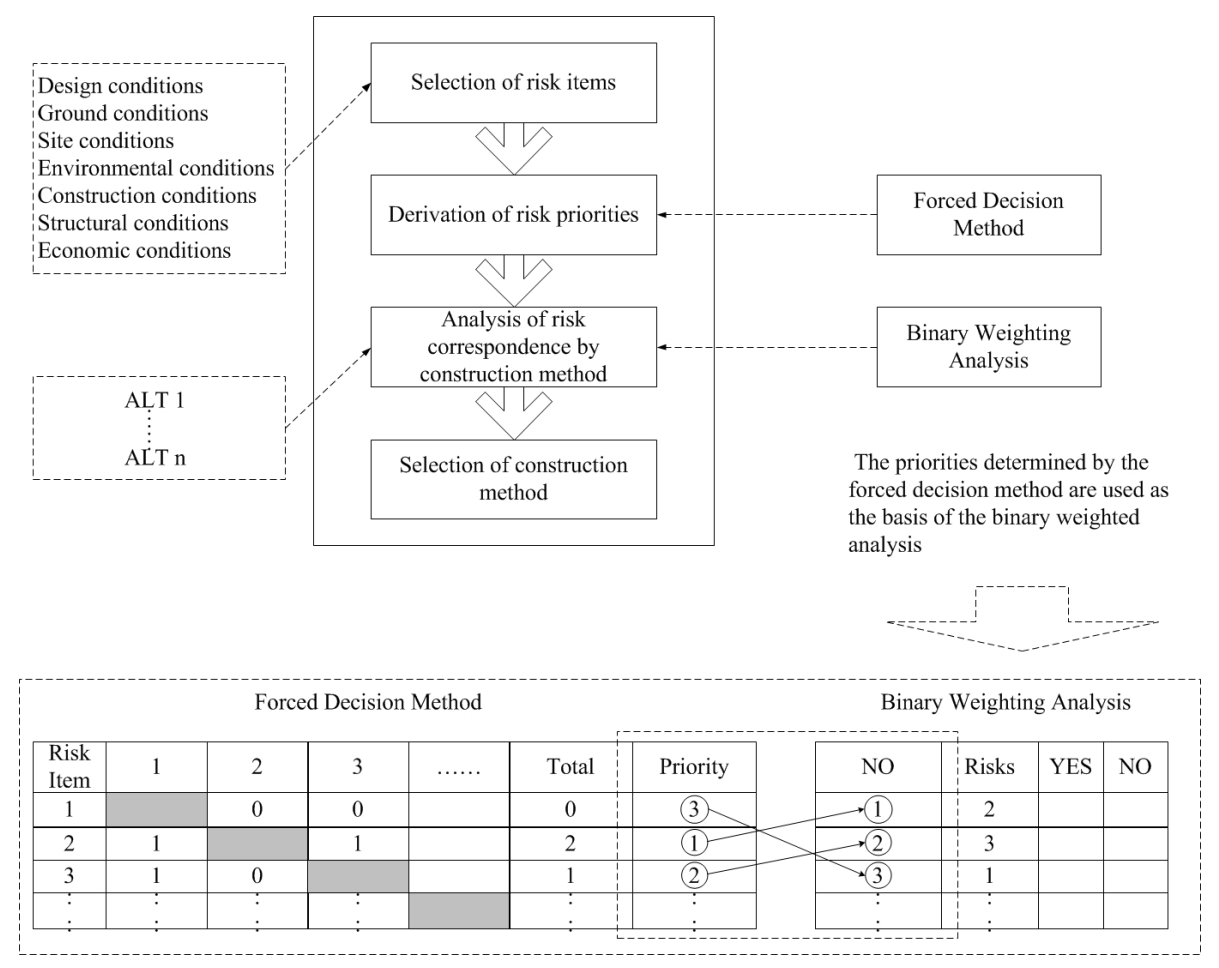

Fig.4. Correlation of Forced Decision Method and Binary Weighting Analysis

Based on the risk priority analysis shown above, an analysis was carried out of the risk correspondence of the multiple walls that were first selected. The risk priority was highest for the Diaphragm Wall, at 0.937 , followed by the Soil Cement Wall, the H-pile + Soil Wall, and Cast In concrete Pile, as shown in Table 14.

Table 14. Evaluation Process and Result

\begin{tabular}{c|c|c|c|c|c}
\hline Ranking & $\begin{array}{l}\text { Review } \\
\text { Factor }\end{array}$ & I & II & III & IV \\
\hline \hline 1 & A & 1 & 1 & 1 & 1 \\
\hline 2 & B & 1 & 0 & 1 & 1 \\
\hline 3 & C & 0 & 1 & 1 & 1 \\
\hline 4 & D & 1 & 1 & 0 & 0 \\
\hline 5 & E & 1 & 1 & 0 & 1 \\
\hline 6 & F & 0 & 1 & 1 & 1 \\
\hline 7 & G & 1 & 0 & 1 & 1 \\
\hline \multicolumn{2}{|c|}{ Rating Value } & 0.858 & 0.740 & 0.906 & 0.937 \\
\hline
\end{tabular}

Note: A-Environmental conditions, B-Ground conditions, C- Design conditions, D-Construction conditions, E-Site conditions, F-Structural conditions, G-Economic conditions, I- H-pile + Soil Wall, II-Cast In concrete Pile, III-Soil Cement Wall, IV-Diaphragm Wall

\section{* Evaluation}

$M E D V=1 \cdot 2^{6}+1 \cdot 2^{5}+1 \cdot 2^{4}+1 \cdot 2^{3}+1 \cdot 2^{2}+1 \cdot 2^{1}+1 \cdot 2^{0}=127$

(1) H-pile + Soil Wall

$E D V=1 \times 2^{6}+1 \times 2^{5}+0 \times 2^{4}+1 \times 2^{3}+1 \times 2^{2}+0 \times 2^{1}+1 \times 2^{0}=109$

$R V=109 / 127=0.858$
(2) Cast In concrete Pile

$E D V=1 \times 2^{6}+0 \times 2^{5}+1 \times 2^{4}+1 \times 2^{3}+1 \times 2^{2}+1 \times 2^{1}+0 \times 2^{0}=94$

$R V=94 / 127=0.740$

(3) Soil Cement Wall

$E D V=1 \times 2^{6}+1 \times 2^{5}+1 \times 2^{4}+0 \times 2^{3}+0 \times 2^{2}+1 \times 2^{1}+1 \times 2^{0}=115$ ......Eq. (9)

$R V=115 / 127=0.906$

(4) Diaphragm Wall

$E D V=1 \times 2^{6}+1 \times 2^{5}+1 \times 2^{4}+0 \times 2^{3}+1 \times 2^{2}+1 \times 2^{1}+1 \times 2^{0}=119$ ......Eq. (11)

$R V=119 / 127=0.937$

\section{Conclusion}

This study presented a model to review the constraints, constructability, stability, and economic efficiency in the planning stage for the selection of the optimum soil retaining wall for a given site. Recently, there has been an increase in the size of underground construction in order to more efficiently use underground spaces in expensive, limited and densely populated areas. Soil retaining walls are consequently diversifying and specializing, and a quantitative analysis model is necessary to determine whether a soil retaining wall can cope with the site risks through the forced decision method and binary weighting analysis. 
This model was then applied to the construction planning stage for a new commercial building in order to verify the possibility of its practical application. This was a basic study to select the optimum soil retaining wall for underground construction in the construction planning stage. In the future, continuous studies are needed to computerize this process model and to develop it into a case-based reasoning process model through many case applications.

\section{References}

1) Fasal, J. (1965) Forced Decisions for Value. Product Engineering. pp.84-86.

2) Joung, K.J., Kwon, W., Oh, S.J., Do, S.Y., and Chun, J.Y. (2004) A study on the Knowledge based selection Process for Proper Construction Method of the Underground construction Phase. Journal of the Architectural Institute of Korea, 24(2). pp.639-642.

3) Kwahk, K. J., Park, M.H., Kim, J.H. and Kim, J.J. (2011) Development of a Progress Management System Integrated with the Quality Inspection Process: Case of a nuclear power plant construction project in Korea. Journal of Asian Architecture and Building Engineering, Vol. 10, No. 2. pp.391-398.

4) Lee, D.H. (2006) An Efficient Owner's Requirements Reflecting Process at the Planning Stage of the Building Project. Doctoral dissertation, Chung-Ang University, Korea.

5) Lee, K., Kim, H., Lee, T. and Han, S. (2012) A Selection Methodology of Slab-form Construction Methods in Residential Buildings based on the Simulation and Delphi Techniques. Journal of Asian Architecture and Building Engineering, Vol. 11, No. 1. pp.39-46.

6) Li, C.S., Guo, S.J. (2012) Life Cycle Cost Analysis of Maintenance Costs and Budgets for University Buildings in Taiwan. Journal of Asian Architecture and Building Engineering, Vol. 11, No. 1. pp.97-94.

7) Moon, H., Lee, H.K., Lee, Y.S. and Kim, J.J. (2007) Earth Information System (EIS) for the Reuse of Resources between Construction Sites. Journal of Asian Architecture and Building Engineering, Vol. 6, No. 2. pp.267-274.

8) Oh, S.J. (2004) An Optimization Model for Design Alternative Selection of Building Elements considering Performance, Cost and Constructability in Building Projects. Doctoral dissertation, Dankook University, Korea.

9) Seo, J.H. (2000) A Study on the Axial Force of Strutting and Anchoring for Retention Structure. Master's dissertation, Chungnam National University, Korea.

10) Tsai, T.C., Yang, M.L. (2009) Risk Management in the Construction Phase of Building Projects in Taiwan. Journal of Asian Architecture and Building Engineering, Vol. 8, No. 1. pp.143-150. 